\title{
Neural Stem Cells: A Perspective and Synopsis of the Current Status
}

\author{
Pradeep G. Bhide ${ }^{a}$ Richard S. Nowakowski ${ }^{b}$ \\ aDevelopmental Neurobiology, Massachusetts General Hospital, Charlestown, Mass., ${ }^{\mathrm{b}}$ Robert Wood Johnson \\ Medical School, Department of Neuroscience and Cell Biology, Piscataway, N.J., USA
}

In the past few years, the words 'stem cells' have appeared in the headlines of newspapers all over the world, on the covers of major scientific journals and even in political debates in many countries. More importantly, however, these words have begun to appear in daily conversations of people interested in stem-cell-based therapies for themselves or for a loved one. In this special issue of Developmental Neuroscience, we add to this discussion and, hopefully, clarify it at least a little.

The focus of this special issue is on one particular type of stem cell, which is called the neural stem cell. In general, stem cells give rise to all cell types of an organism and have the ability to self-renew - characteristics that distinguish these cells from progenitor cells and precursor cells. Neural stem cells give rise to neurons and glia and are common in the neural plate of the embryo and in the proliferative zones throughout the anterior-posterior axis of the developing nervous system. In the adult nervous system, the current idea is that stem cells persist only in relatively small numbers and only in a few locations. Despite their sparseness, stem cells in the adult nervous system share a number of properties with their embryonic counterparts, such as the ability to self-renew and to generate multiple cell types. Recent reports that stem cells in the adult nervous system can be induced to generate neurons and glia has stimulated discussion of the possibility that the neurons generated by the stem cells can re-establish functional connections damaged by injury or disease. Interest in the therapeutic uses of neural stem cells has brought into sharp focus the need for a greater understanding of the biology of the stem cell in the developing and adult nervous system.

This special issue assembles research reports and minireviews on exciting new developments in neural stem cell biology in the embryonic and mature nervous system, from the perspectives of basic and clinical neuroscience. Some of the questions addressed from the basic science perspective are: What factors regulate the generation of the different cell types from stem cells during normal development? What factors contribute to the development of regional diversity in cell types and cell numbers? And, how do genetic and environmental factors interact to influence stem cell function? The questions addressed from the applied or clinical neuroscience perspective are: How can understanding neural stem cell function in the nervous system help understand the role of stem cells in mediating the effects of brain trauma or recovery from it? And, can stem cells be used as therapeutic agents to deliver genes to the injured brain? By bringing together multiple perspectives, we hope that this special issue on neural stem cell biology will be a valuable resource for neuroscientists and clinicians alike.

\begin{tabular}{ll}
\hline KARGER & ( ) 2004 S. Karger AG, Basel \\
0378-5866/04/0264-0081\$21.00/0 \\
$\begin{array}{l}\text { Fax +4161306 12 34 } \\
\begin{array}{l}\text { E-Mail karger@karger.ch } \\
\text { www.karger.com }\end{array}\end{array}$ & $\begin{array}{l}\text { Accessible online at: } \\
\text { www.karger.com/dne }\end{array}$
\end{tabular}

Dr. Pradeep G. Bhide

Developmental Neurobiology, Massachusetts General Hospital

149, 13th Street

Charlestown, MA 02129 (USA)

Tel. +1 617726 5763, Fax +1617 726 6656, E-Mail bhide@helix.mgh.harvard.edu 